Check for updates

Cite this: RSC Adv., 2017, 7, 41011

Received 24th April 2017

Accepted 16th August 2017

DOI: $10.1039 / \mathrm{c} 7 \mathrm{ra04587e}$

rsc.li/rsc-advances

\title{
In situ ATR-FTIR investigation and theoretical calculation of the interactions of chromate and citrate on the surface of haematite $\left(\alpha-\mathrm{Fe}_{2} \mathrm{O}_{3}\right)$
}

\begin{abstract}
W. G. Gao, (D) ${ }^{\text {ac }}$ X. C. Liu ${ }^{\mathrm{b}}$ and M. F. Chen ${ }^{\star a}$
In situ attenuated total reflectance Fourier transform infrared (ATR-FTIR) spectroscopy was used to study the molecular kinetics of $\mathrm{Cr}(\mathrm{VI})$ reduction by citric acid at the $\alpha-\mathrm{Fe}_{2} \mathrm{O}_{3}$-water interface. Both citrate and $\mathrm{Cr}(\mathrm{VI})$ were adsorbed to the surface of $\alpha-\mathrm{Fe}_{2} \mathrm{O}_{3}$ through the formation of stable monodentate and bidentate complexes. Chromate was potentially reduced by citric acid hydroxyl groups $\left(-\mathrm{COO}^{-}\right)$on the $\alpha-\mathrm{Fe}_{2} \mathrm{O}_{3}$ surface sites. Monodentate complexes were favoured at $\mathrm{pH} 4.0$ due to strong electrostatic attraction forces between the ions and minerals. Density functional theory was used to calculate the adsorption and interaction processes of $\mathrm{Cr}(\mathrm{VI})$ and citrate on $\alpha-\mathrm{Fe}_{2} \mathrm{O}_{3}$; the calculations indicated that the adsorption of $\mathrm{Cr}(\mathrm{VI})$ or citrate can occur spontaneously and result in the formation of stable complexation structures. However, the co-adsorption of $\mathrm{Cr}(\mathrm{VI})$ and citrate on $\alpha-\mathrm{Fe}_{2} \mathrm{O}_{3}$ is energetically unstable and leads to the initiation of redox reactions on the $\alpha-\mathrm{Fe}_{2} \mathrm{O}_{3}$ surface. These findings have important implications for the fate of chromate in the environment. Therefore, our work describes the molecular mechanism of $\mathrm{Cr}(\mathrm{vI})$ reduction by citrate on the surface of $\alpha-\mathrm{Fe}_{2} \mathrm{O}_{3}$ for the first time. The results can be correlated to the fate of chromate in the environment in the presence of $\alpha-\mathrm{Fe}_{2} \mathrm{O}_{3}$ and low molecular weight organic acids.
\end{abstract}

\section{Introduction}

Chromium(vi) (Cr(vi)) is one of the most frequently detected industrial groundwater contaminants. $\mathrm{Cr}(\mathrm{vI})$ is a carcinogen, and it exists in an oxyanionic form as chromate. The fate of $\mathrm{Cr}(\mathrm{vI})$ depends on its adsorption reactions on mineral surfaces in the absence of reducing conditions. ${ }^{1}$ Adsorption onto minerals is a common method for removing $\mathrm{Cr}(\mathrm{VI})$ from the environment. $^{2}$ The reduction of $\mathrm{Cr}(\mathrm{VI})$ to $\mathrm{Cr}(\mathrm{III})$ is another important strategy for detoxifying $\mathrm{Cr}(\mathrm{vI})$-contaminated sites, and it is an effective treatment method.

Several studies have investigated the rapid removal of $\mathrm{Cr}(\mathrm{vI})$ from solutions using different types of adsorbents, such as metal oxides, ${ }^{3}$ and minerals. ${ }^{4}$ The molecular mechanisms of $\mathrm{Cr}$ (vi) adsorption on iron oxides were recently investigated by Johnston et al., ${ }^{5}$ who used theoretical calculations and in situ attenuated total reflected Fourier transformed infrared spectroscopy (ATR-FTIR) to elucidate the adsorption structure of $\mathrm{Cr}(\mathrm{vI})$ on the surface of hematite. $\mathrm{Cr}(\mathrm{vI})$ can also be reduced to $\mathrm{Cr}(\mathrm{III})$ using natural organic matter (NOM); this process is

${ }^{a}$ Key Laboratory of Soil Environment and Pollution Remediation, Institute of Soil Science, Chinese Academy of Sciences, Nanjing 210008, China. E-mail: mfchen@ issas.ac.cn

${ }^{b}$ State Key Laboratory for Coal Conversion, Institute of Coal Chemistry, Chinese Academy of Sciences, Taiyuan 130100, China

'University of the Chinese Academy of Sciences, Beijing 100049, China greatly affected by the presence of coexisting metal ions ${ }^{6}$ and the properties of the minerals. ${ }^{7}$

The interactions between $\mathrm{Cr}(\mathrm{vI})$ and natural organic acids at mineral-water interfaces have become an increasingly important area of interest when considering the behaviour and toxicity of $\mathrm{Cr}(\mathrm{vI})$ in the environment. As one of the most ubiquitous natural organic acids, citric acid is an exudate of plants and can reduce $\mathrm{Cr}(\mathrm{VI})$ into $\mathrm{Cr}(\mathrm{III})$ under certain conditions. Earlier studies have confirmed that mineral surfaces can act as catalysts for redox reactions between $\mathrm{Cr}(\mathrm{vI})$ and citric acids to form nontoxic $\mathrm{Cr}(\mathrm{III}) \cdot{ }^{8-11}$ But the molecular mechanisms of their interactions at mineral-water interfaces remain unclear.

In this study, the molecular kinetics of $\mathrm{Cr}(\mathrm{vI})$ reduction by citrate on the surface of $\alpha-\mathrm{Fe}_{2} \mathrm{O}_{3}$ was investigated in situ by using ATR-FTIR spectroscopy. Density functional theory (DFT) was used to calculate the electron densities and variations of the interactions between $\mathrm{Cr}(\mathrm{vI})$ and citrate at $\mathrm{Fe}_{2} \mathrm{O}_{3}$-water interfaces with different environmentally relevant $\mathrm{pH}$ values. We hypothesized that negatively charged $\mathrm{Cr}(\mathrm{vI})$ and citrate would adsorb to the positively charged $\alpha-\mathrm{Fe}_{2} \mathrm{O}_{3}$ surface through the formation of monodentate complexes due to electrostatic attraction. Based on this assumption, the binding and free energies of the clusters were calculated to infer their possible reaction pathways. Our findings elucidate how these reactions occur at the molecular level. 


\section{Materials and methods}

\subsection{Chemicals}

All chemicals and reagents were of analytical grade or higher purity and were used as received, and all solutions were prepared using Millipore filtered water (18 M $\Omega$, Millipore Corp.). $\alpha-\mathrm{Fe}_{2} \mathrm{O}_{3}$ was purchased from Sino Chemicals Corp., with a purity of more than $99.9 \%$. Powder X-ray diffraction (XRD) was used to determine the bulk crystalline phase of the $\alpha-\mathrm{Fe}_{2} \mathrm{O}_{3}$. The BET surface area of the studied $\alpha-\mathrm{Fe}_{2} \mathrm{O}_{3}$ was $4.08 \pm 0.02 \mathrm{~m}^{2} \mathrm{~g}^{-1}$. For in situ ATR-FTIR experiments, $\alpha-\mathrm{Fe}_{2} \mathrm{O}_{3}$ was suspended in Millipore water by sonicating for 6 hours before use.

\subsection{In situ ATR-FTIR analysis}

In situ flow cell ATR-FTIR spectroscopy was performed using a Bruker FTIR (Bruker Optics) spectrometer equipped with a multi-bounce PIKE flow cell part (PIKE Corp.). Data collection and analyses were performed using the OPUS software package (v6.5). Scans were recorded from 4000 to $400 \mathrm{~cm}^{-1}$ at a resolution of $8 \mathrm{~cm}^{-1} \cdot \alpha-\mathrm{Fe}_{2} \mathrm{O}_{3}$ film coatings $(\sim 0.5 \mathrm{mg})$ were prepared by depositing $0.8 \mathrm{~mL}$ of the $\alpha-\mathrm{Fe}_{2} \mathrm{O}_{3}$ suspension on a $\mathrm{ZnSe}$ internal reflection element (IRE) and were dried under a stream of nitrogen gas. Next, the IRE was mounted on a flow cell with a peristaltic pump to allow a specified volume of solution to pass over the film. The concentrations of $\mathrm{Cr}(\mathrm{vI})$ and citric acid were set at $0.1 \mathrm{mM}$ each, and the solution $\mathrm{pH}$ was adjusted by titrating with $0.1 \mathrm{M} \mathrm{HNO}_{3}$ or $\mathrm{NaOH}$. Before the adsorption experiment, the film was equilibrated with $\mathrm{H}_{2} \mathrm{O}(18 \mathrm{M} \Omega)$ at the specified $\mathrm{pH}$ for $20 \mathrm{~min}$. The flow rate was set to approximately 1 $\mathrm{mL} \min ^{-1}$.

\subsection{DFT calculations}

The theoretical frequencies of the possible surface complex structures were calculated using the approach described by Kubicki et al. ${ }^{12}$ The $\mathrm{Fe}_{2} \mathrm{O}_{3}$ surface was represented using an $\mathrm{Fe}_{2} \mathrm{O}_{x} \mathrm{H}_{y}$ di-iron hydroxide cluster model that consisted of two octahedrally coordinated Fe atoms connected via two Fe-(OH)Fe linkages. This model has been used in many other theoretical studies and has been proven valid. All calculations were performed using the Gaussian09 package and run on the Tianhe-2 supercomputer at the LvLiang Cloud Computing Center. DFT calculations were performed using the B3LYP method $^{5,13}$ and the $6-311 \mathrm{G}++(\mathrm{d}, \mathrm{p})$ basis set. The geometries of the clusters were optimized using the Berny algorithm and GEDIIS with redundant internal coordinates to a potential energy minimum without symmetry or geometrical constraints. Next, the clusters were analysed for harmonic frequencies. Short-range solvation effects were accounted for by using 3 explicit water molecules, and the long-range solvation effect was modelled using the integral equation formalism version of the polarizable continuum model (PCM). ${ }^{14}$ All atomic charges were calculated based on the natural bond orbital (NBO) population analysis code in Gaussian09.

Because the $\mathrm{Fe}_{2} \mathrm{O}_{3}$ surface should be protonated and saturated with water molecules in aqueous solutions, the adsorption of either $\mathrm{HCrO}_{4}{ }^{-}$or citrate would not occur unless one or more of the saturating $\mathrm{H}_{2} \mathrm{O}$ molecules were replaced by the adsorbents. We defined the adsorption energy and free energy by using the following chemical equation:

$$
\text { Ion }+ \text { cluster } \cdot 3 \mathrm{H}_{2} \mathrm{O}=\text { ion_cluster } \cdot 4 \mathrm{H}_{2} \mathrm{O}
$$

where "ion_cluster $4 \mathrm{H}_{2} \mathrm{O}$ " indicates the substitution of a coordinating water molecule with an incoming ion and the water molecule becomes an additional explicit solvent molecule.

Thus we have:

$$
\begin{aligned}
& \Delta E_{\mathrm{ad}}=E\left(\text { ion_cluster } \cdot 4 \mathrm{H}_{2} \mathrm{O}\right)-E(\text { ion })-E\left(\text { cluster } \cdot 3 \mathrm{H}_{2} \mathrm{O}\right) \\
& \Delta G_{\mathrm{ad}}=G\left(\text { ion_cluster } \cdot 4 \mathrm{H}_{2} \mathrm{O}\right)-G(\text { ion })-G\left(\text { cluster } \cdot 3 \mathrm{H}_{2} \mathrm{O}\right)
\end{aligned}
$$

In the case of co-adsorption,

$$
\begin{aligned}
\Delta E_{\mathrm{ad}}= & E\left(\text { ionA_ionB_cluster } \cdot 5 \mathrm{H}_{2} \mathrm{O}\right)-E(\text { ionA })-E(\text { ionB }) \\
& -E\left(\text { cluster } \cdot 3 \mathrm{H}_{2} \mathrm{O}\right) \\
\Delta G_{\mathrm{ad}}= & G\left(\text { ionA_ionB_cluster } \cdot 5 \mathrm{H}_{2} \mathrm{O}\right)-G(\text { ionA })-G(\text { ionB }) \\
& -G\left(\text { cluster } \cdot 3 \mathrm{H}_{2} \mathrm{O}\right)
\end{aligned}
$$

\section{Results and discussion}

\subsection{In situ ATR-FTIR studies of $\mathrm{Cr}(\mathrm{vI})$ and citrate on $\alpha-\mathrm{Fe}_{2} \mathrm{O}_{3}$}

3.1.1 Adsorption of $\mathrm{Cr}(\mathrm{vI})$ on the $\mathrm{Fe}_{2} \mathrm{O}_{3}$ film as a function of time and pH. Fig. 1 displays the ATR-FTIR spectra of $\alpha-\mathrm{Fe}_{2} \mathrm{O}_{3}$ exposed to $0.1 \mathrm{mM}$ chromate at $\mathrm{pH} 2.0,4.0,6.0$ and 8.0 (as shown in Fig. 1A, B, C and D, respectively) as a function of time. The depicted frequency range corresponding to the region of $\mathrm{Cr}-\mathrm{O}$ stretching vibrations of $\mathrm{HCrO}_{4}{ }^{-}$and $\mathrm{CrO}_{4}{ }^{2-}$ in solution is between 800 and $950 \mathrm{~cm}^{-1} \cdot{ }^{15}$ The chromate signals in Fig. 1

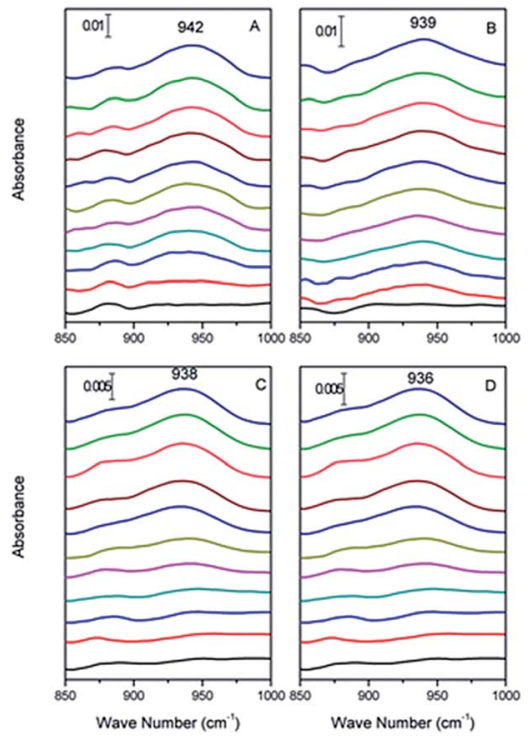

Fig. 1 In situ ATR-FTIR spectrum of $\mathrm{Cr}(\mathrm{vI})$ adsorbed on haematite film at $\mathrm{pH}$ (A) 2.0, (B) 4.0, (C) 6.0, and (D) 8.0, respectively, from 0 to $30 \mathrm{~min}$ (from bottom to top). 


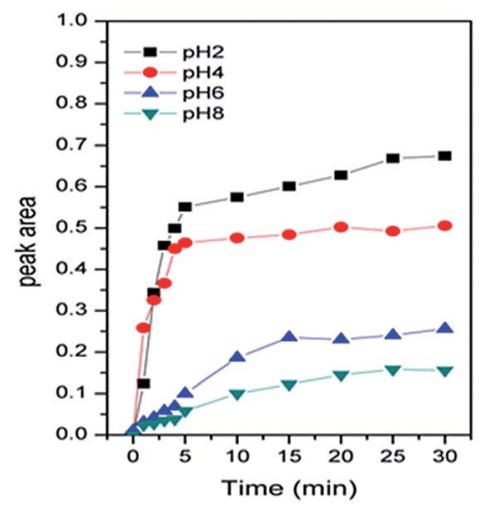

Fig. 2 Areas of the IR peaks from $\mathrm{Cr}(\mathrm{vI})$ adsorbed on haematite at different $\mathrm{pH}$ values.

were attributed to its adsorption on the $\alpha-\mathrm{Fe}_{2} \mathrm{O}_{3}$ because the chromate concentration in solution $(0.1 \mathrm{mM})$ was well below the detection limit $(>10 \mathrm{mM})$.

Specifically, the $\mathrm{Cr}(\mathrm{vI})$ adsorbed on $\alpha-\mathrm{Fe}_{2} \mathrm{O}_{3}$ resulted in spectral features at 942, 939, 938 and $936 \mathrm{~cm}^{-1}$ at pH 2.0, 4.0, 6.0 , and 8.0, respectively. In addition, the data obtained for $\mathrm{pH}$ 2.0, 4.0, 6.0 and 8.0 showed similar vibrational modes of $\mathrm{Cr}-\mathrm{O}$ that increased with time and reached equilibrium after $30 \mathrm{~min}$ with no visible changes. We attributed the increased intensity of the spectral features representing associated $\mathrm{Cr}(\mathrm{vI})$ to its adsorption to the $\alpha-\mathrm{Fe}_{2} \mathrm{O}_{3}$ surface. To qualify the interface absorption kinetics of $\mathrm{Cr}(\mathrm{vI})$, the peak areas of the $\mathrm{Cr}-\mathrm{O}$ stretching vibrations at each specific $\mathrm{pH}$ were calculated as a function of time, as shown in Fig. 2, which is consistent with the expectation that chromate absorption on the $\alpha-\mathrm{Fe}_{2} \mathrm{O}_{3}$ increased as the $\mathrm{pH}$ decreased, as previously overserved in batch studies. ${ }^{16,17}$

3.1.2 Adsorption of citric acid on the $\mathrm{Fe}_{2} \mathrm{O}_{3}$ film as a function of time and $\mathbf{p H}$. Fig. 3 displays the ATR-FTIR spectra of citric acid adsorbed on $\alpha-\mathrm{Fe}_{2} \mathrm{O}_{3}$ film at pH 2.0, 4.0, 6.0 and 8.0 (Fig. 3A,
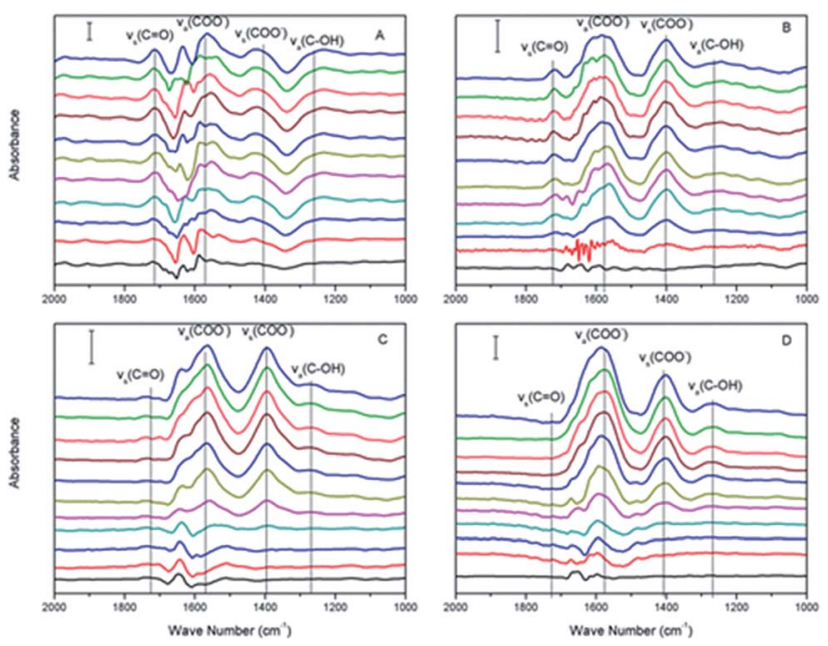

Fig. 3 In situ ATR-FTIR spectra of citrate adsorbed on haematite film at $\mathrm{pH}$ (A) 2.0, (B) 4.0, (C) 6.0, and (D) 8.0, respectively, from 0 to $30 \mathrm{~min}$ (from bottom to top).
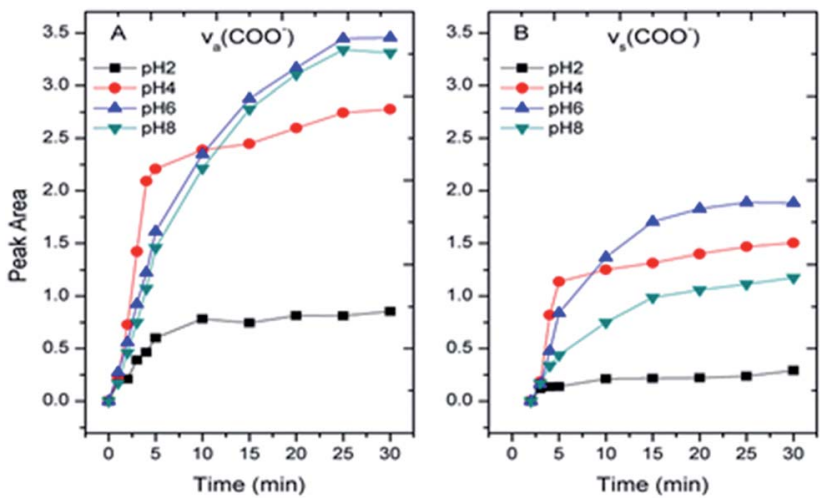

Fig. 4 Areas of the IR peaks from the carboxyl radicals $\left(-\mathrm{COO}^{-}\right)$of citrate adsorbed on haematite at different $\mathrm{pH}$ values.

$\mathrm{B}, \mathrm{C}$ and D, respectively) as a function of time. Similar to $\mathrm{Cr}(\mathrm{vI})$ adsorption, spectral features resulted from the sorption of citric acid to the $\alpha-\mathrm{Fe}_{2} \mathrm{O}_{3}$ film. The most representative citric acid radicals were $-\mathrm{COOH}$ and $-\mathrm{COO}^{-}$, and protons were hydrolysed from the citric acid molecules. The carbonyl double bond $\left(v_{\mathrm{C}}=\mathrm{O}\right)$ of the $-\mathrm{COOH}$ radical resulted in a peak at $1740 \mathrm{~cm}^{-1}$, the single carboxyl radical resulted in a peak at $1740 \mathrm{~cm}^{-1}$, and the single carboxyl bond $\left(\nu_{\mathrm{C}-\mathrm{OH}}\right)$ position of the $-\mathrm{COOH}$ radical resulted in a peak at $1270 \mathrm{~cm}^{-1}$, as reported by Bhandari et al. ${ }^{18}$ and Max and Chapados. ${ }^{19}$ The peak at $1400 \mathrm{~cm}^{-1}$ was interpreted as the symmetric vibrations of ionized $-\mathrm{COO}^{-}$radicals $\left(\nu_{\mathrm{s}}\left(\mathrm{COO}^{-}\right)\right)$, and the frequency range of $1570-1595 \mathrm{~cm}^{-1}$ was attributed to the asymmetric vibrations of the ionized $-\mathrm{COO}^{-}$radicals $\left(\nu_{\text {as }}\left(\mathrm{COO}^{-}\right)\right) .{ }^{19}$ The intensity of the peaks from the vibrations of these radicals slightly changed with $\mathrm{pH}$, especially the intensities of $\nu_{\mathrm{as}}\left(\mathrm{COO}^{-}\right)$and $\nu_{\mathrm{s}}\left(\mathrm{COO}^{-}\right)$as the hydrolysis of protons from the citric acid occurred with increasing $\mathrm{pH}$.

Within the equilibrium $\mathrm{pH}$ range, citric acids were expected to gradually dissociate and remain deprotonated (negatively charged), and the surface of $\alpha-\mathrm{Fe}_{2} \mathrm{O}_{3}$ was expected to remain positively charged $\left(\mathrm{pH}_{\text {zeta }} \approx 8.4\right)$. The $-\mathrm{COO}^{-}$radicals become adsorbed to the $\alpha-\mathrm{Fe}_{2} \mathrm{O}_{3}$ surface via electrostatic attraction when the solution $\mathrm{pH}$ is greater than the $\mathrm{p} K_{\mathrm{a} 1}$ of citric acid. The areas of the $\nu_{\text {as }}\left(\mathrm{COO}^{-}\right)$and $\nu_{\mathrm{s}}\left(\mathrm{COO}^{-}\right)$peaks were calculated to study their absorption kinetics on the $\alpha-\mathrm{Fe}_{2} \mathrm{O}_{3}$ surface, as shown in Fig. $4 \mathrm{~A}$ and $\mathrm{B}$, respectively. As the $\mathrm{pH}$ increased, the intensities of $\nu_{\text {as }}\left(\mathrm{COO}^{-}\right)$and $\nu_{\mathrm{s}}\left(\mathrm{COO}^{-}\right)$increased and were maximized at $\mathrm{pH}$ 6.0. Although the maximum electronegativity of citric acid should occur at $\mathrm{pH}>8.0$, the surface of $\alpha-\mathrm{Fe}_{2} \mathrm{O}_{3}$ is negatively charged when the solution $\mathrm{pH}$ is greater than its isoelectric point, which would prevent the adsorption of more $-\mathrm{COO}^{-}$radicals on $\alpha-\mathrm{Fe}_{2} \mathrm{O}_{3}$.

3.1.3 Sequent exposure of $\mathrm{Cr}(\mathrm{vI})$ and citrate. Fig. 5 displays the in situ ATR-FTIR results of the sequential flow of $0.1 \mathrm{mM}$ $\mathrm{Cr}(\mathrm{vI})$ and $0.1 \mathrm{mM}$ citric acid solutions at $\mathrm{pH} 4.0$ on $\alpha-\mathrm{Fe}_{2} \mathrm{O}_{3}$ film (A and $\mathrm{B}$, respectively) as a function of time. The ATRabsorbance signal of bichromate on the $\alpha-\mathrm{Fe}_{2} \mathrm{O}_{3}$ film increased with time in our experiment (Fig. $5 \mathrm{~A}(\mathrm{a}, \mathrm{b}, \mathrm{c}, \mathrm{d}$ and e), respectively) and exhibited a characteristic spectral peak at $942 \mathrm{~cm}^{-1}$. The increased intensity of the $\operatorname{Cr}(\mathrm{vI})$ at this stage was attributed to its adsorption on the $\alpha-\mathrm{Fe}_{2} \mathrm{O}_{3}$ film. The intensity of 


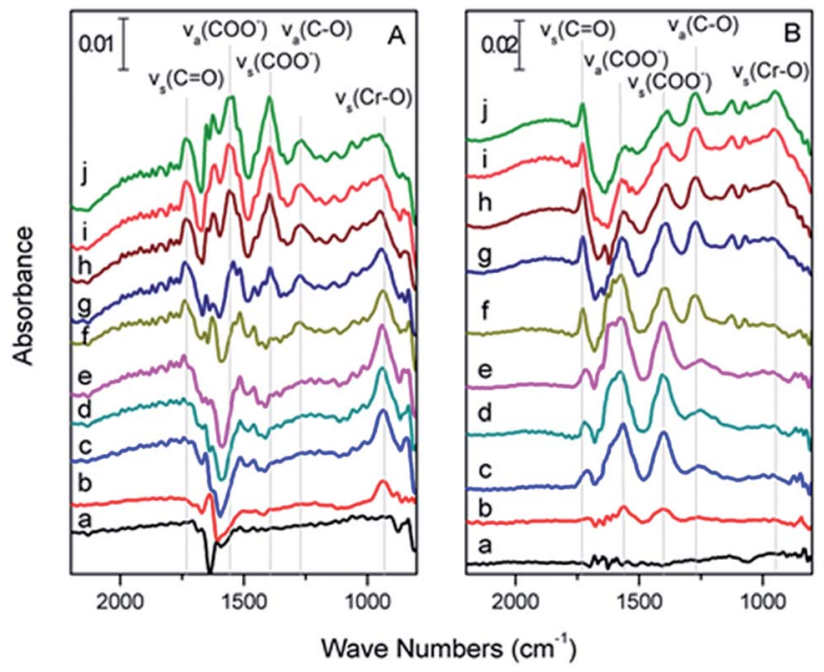

Fig. 5 (A) In situ ATR-FTIR spectrum of haematite (a) flushed with $\mathrm{pH}$ 4.0 $\mathrm{H}_{2} \mathrm{O}$ for $15 \mathrm{~min}$ and after subsequent exposure to a flowing solution of $0.1 \mathrm{mM} \mathrm{Cr}(\mathrm{vI})$ at pH 4.0 for (b) 1, (c) 5, (d) 15 and (e) $30 \mathrm{~min}$ and (f) flushed with $\mathrm{pH} 4 \mathrm{H}_{2} \mathrm{O}$ for $20 \mathrm{~min}$ and after subsequent exposure to a flowing solution of $0.1 \mathrm{mM}$ citric acid at $\mathrm{pH} 4$ for (g) 1, (h) 5, (i) 15, and (j) $30 \mathrm{~min}$ (B) in situ ATR-FTIR spectrum of haematite (a) flushed with $\mathrm{pH} 4.0 \mathrm{H}_{2} \mathrm{O}$ for $15 \mathrm{~min}$ and after subsequent exposure to a flowing solution of $0.1 \mathrm{mM}$ citric acid at pH 4.0 for (b) 1, (c) 5, (d) 15 and (e) $30 \mathrm{~min}$; and (f) flushed with $\mathrm{pH} 4 \mathrm{H}_{2} \mathrm{O}$ for $20 \mathrm{~min}$ and after subsequent exposure to a flowing solution of $\mathrm{Cr}(\mathrm{vl}) 0.1 \mathrm{mM}$ at $\mathrm{pH} 4$ for (g) 1, (h) 5, (i) 15, and (j) $30 \mathrm{~min}$.

$\nu(\mathrm{Cr}=\mathrm{O})$ slightly decreased after flushing with water at $\mathrm{pH} 4$ for 20 min until equilibrium was reached (Fig. 5A-f), at which time $0.1 \mathrm{mM}$ citric acid at $\mathrm{pH} 4$ was introduced into the ATR flow cell. The intensity of $\nu(\mathrm{Cr}=\mathrm{O})$ gradually decreased and disappeared after $30 \mathrm{~min}$. However, this result did not exclude the adsorbed $\mathrm{Cr}(\mathrm{vI})$ that was displaced by the citric acid via a competitive adsorption mechanism.

During the flow sequence, the characteristic peaks of citric acid grew with time (Fig. 5B(a, b, c, d, and e), respectively), which meant that the citric acid was adsorbed on the $\alpha-\mathrm{Fe}_{2} \mathrm{O}_{3}$ film. Because $-\mathrm{COOH}$ and $-\mathrm{COO}^{-}$had different vibration modes, as mentioned above, we inferred that the $-\mathrm{COOH}$ and $-\mathrm{COO}^{-}$functional groups of citric acid were both adsorbed to the $\alpha-\mathrm{Fe}_{2} \mathrm{O}_{3}$ surface. The vibration intensity of the citric acid remained stable when flushed with water at $\mathrm{pH} 4$ water (Fig. 5B-f) for $20 \mathrm{~min}$, at which time the $\mathrm{pH} 4.0 \mathrm{Cr}(\mathrm{vI})$ solution was pumped into the ATR flow cell. Interestingly, as the intensity of the $\nu(\mathrm{Cr}=\mathrm{O})$ peak increased, the intensities of the $\nu_{\mathrm{s}}\left(\mathrm{COO}^{-}\right)$and $\nu_{\text {as }}\left(\mathrm{COO}^{-}\right)$peaks gradually decreased. However, the intensities of the $\nu_{\mathrm{S}}(\mathrm{C}=\mathrm{O})$ and $\nu_{\text {as }}(\mathrm{C}-\mathrm{O})$ peaks of the $-\mathrm{COOH}$ radicals remained the same throughout the experiment (Fig. $5 \mathrm{~B}(\mathrm{~g}, \mathrm{~h}, \mathrm{i}$ and $\mathrm{j}$ ), respectively), which indicated that the adsorbed $-\mathrm{COO}^{-}$radical was the electron supplier rather than the $-\mathrm{COOH}$ radical of citric acid.

\subsection{DFT calculations}

3.2.1 The structures and adsorption energetics of citrate and $\mathrm{Cr}(\mathrm{vI})$ on $\mathrm{Fe}_{2} \mathrm{O}_{3}$. The optimized structures of the di-iron
A
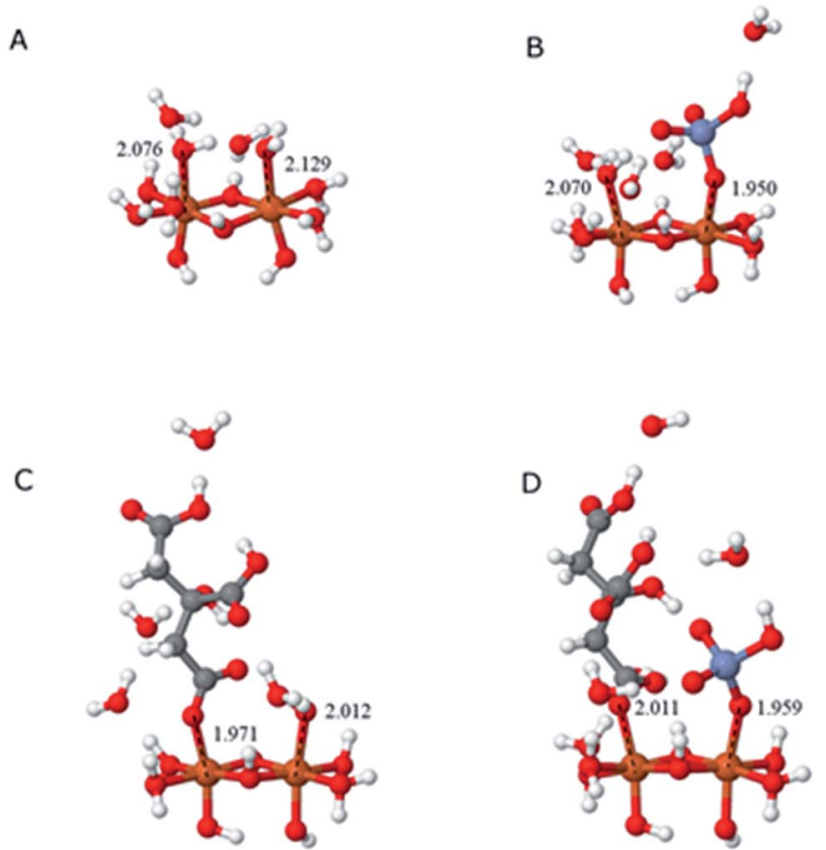

Fig. 6 The optimized structures of the di-iron hydroxide cluster (A), with $\mathrm{HCrO}_{4}{ }^{-}$adsorption (B), citrate adsorption (C), and $\mathrm{HCrO}_{4}{ }^{-}$and citrate co-adsorption (D). Fe: orange, O: red, Cr: dark blue, C: grey, and $\mathrm{H}$ : white.

clusters and their adsorbed species are shown in Fig. 6. In the di-iron cluster, the water molecules were loosely coordinated with the $\mathrm{Fe}$ atoms. The adsorption of citrate and $\mathrm{HCrO}_{4}{ }^{-}$ions decreased the $\mathrm{Fe}-\mathrm{O}$ distance, which indicted that both ions were more strongly bound to the Fe-O bonds. This result was confirmed by the negative adsorption energy changes shown in Table 1. Both citrate and $\mathrm{HCrO}_{4}{ }^{-}$ions have similar adsorption energies of approximately $-70 \mathrm{~kJ} \mathrm{~mol}^{-1}$.

The co-adsorption state $\left(-106.25 \mathrm{~kJ} \mathrm{~mol}^{-1}\right)$ is energetically less favourable than the independent adsorption of both ions (153.05 $\mathrm{kJ} \mathrm{mol}^{-1}$ ), presumably due to steric electronic effects.

As expected, adsorption causes monomers to lose some degree of freedom and is unfavourable in terms of entropy change. This effect is reflected by the difference in the adsorption energies and the adsorption free energies. The entropic effect results in a coadsorption free energy of only $-1.38 \mathrm{~kJ} \mathrm{~mol}^{-1}$; thus, the coadsorption state is not very stable and may cause conformational changes, such as desorption or redox reactions. Redox reactions were favoured in this study.

3.2.2 The highest molecular orbitals (HOMO) and lowest unoccupied orbitals (LUMO) before and after citrate and $\mathrm{Cr}(\mathrm{vI})$ adsorption. The tendency of electron flow can be illustrated by the HOMO orbitals before and after adsorption. When considering an isolated citrate ion (Fig. 7C), the most active electrons (those in the HOMO orbital) mainly reside in carboxylate groups, which are negatively charged. When the carboxylate groups are adsorbed on the cluster, the most active electrons would move to the iron cluster (Fig. 7D). When $\mathrm{HCrO}_{4}{ }^{-}$is further co-adsorbed (Fig. 7E), the most active electrons are shared by $\mathrm{HCrO}_{4}{ }^{-}$and the iron cluster. In other words, some of 
Table 1 Adsorption energy and free energy of the interactions of $\mathrm{HCrO}_{4}{ }^{-}$and citrate with the di-iron hydroxide cluster

\begin{tabular}{lccc}
\hline Energy & $\mathrm{HCrO}_{4}{ }^{-}$ & Citrate & $\mathrm{HCrO}_{4}{ }^{-}+$citrate \\
\hline$\Delta E_{\mathrm{ad}}\left(\mathrm{kJ} \mathrm{mol}^{-1}\right)$ & -73.06 & -79.99 & -106.25 \\
$\Delta G_{\mathrm{ad}}\left(\mathrm{kJ} \mathrm{mol}^{-1}\right)$ & -24.94 & -38.51 & -1.38 \\
\hline
\end{tabular}

LUMO
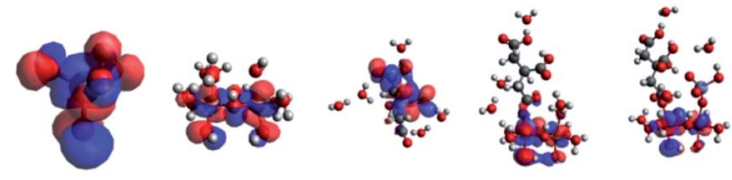

HOMO
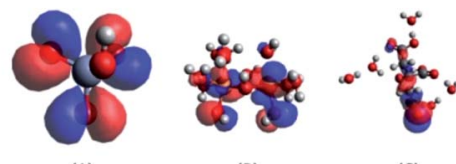

(C)
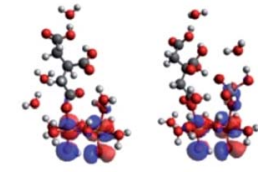

(D)
Fig. 7 The $\mathrm{HOMO}$ and LUMO levels of $\mathrm{HCrO}_{4}^{-}$(A), the $\mathrm{Fe}_{2} \mathrm{O}_{3}$ cluster (B), citrate (C), the citrate adsorption on the di-iron hydroxide cluster (D), and the citrate and $\mathrm{HCrO}_{4}^{-}$co-adsorption on the di-iron hydroxide cluster (E).

the active electrons flow from the iron cluster to $\mathrm{HCrO}_{4}{ }^{-}$. This result supports our hypothesis that $\mathrm{Fe}_{2} \mathrm{O}_{3}$ works as a bridge for the transfer of electrons between citrate and $\mathrm{Cr}(\mathrm{vI})$.

The interactions between citrate and $\mathrm{Fe}_{2} \mathrm{O}_{3}$ clusters involve electron flow from citrate to $\mathrm{Fe}_{2} \mathrm{O}_{3}$; hence, the HOMO orbitals of citrate will interact with the LUMO orbitals of $\mathrm{Fe}_{2} \mathrm{O}_{3}$ (Fig. 7B). As Fig. 7C shows, the HOMO orbital of citrate mostly resides on the bottom (carboxyl group), indicating that it will bind with $\mathrm{Fe}_{2} \mathrm{O}_{3}$ clusters through the carboxyl groups; this binding is evidenced by the interaction model in Fig. 7D. Despite the citrate adsorption, the LUMO orbital of the citrate- $\mathrm{Fe}_{2} \mathrm{O}_{3}$ complex is still located on the $\mathrm{Fe}_{2} \mathrm{O}_{3}$ part, showing that it still has the ability to attract $\mathrm{HCrO}_{4}{ }^{-}$through the interaction between its LUMO orbital and the HOMO orbital of $\mathrm{HCrO}_{4}{ }^{-}$(Fig. 7A). This observation proves that $\mathrm{Fe}_{2} \mathrm{O}_{3}$ is able to serve as a catalytic substrate for the co-adsorption and further reaction of citrate and $\mathrm{HCrO}_{4}{ }^{-}$, and this behaviour is in line with our experimental observations.

\subsection{Reaction mechanisms}

3.3.1 Adsorption mechanisms. In situ ATR-FTIR spectroscopy showed that both $\mathrm{Cr}(\mathrm{vI})$ and citrate could adsorb to the $\alpha-\mathrm{Fe}_{2} \mathrm{O}_{3}$ surface. Citric acid and chromate could be adsorbed on the $\alpha-\mathrm{Fe}_{2} \mathrm{O}_{3}$ surface through electrostatic reactions, surface hydroxyl exchange or hydrogen bonding, which would result in absorbance IR spectra after the exposure of the solute to the $\alpha-\mathrm{Fe}_{2} \mathrm{O}_{3}$ film. ${ }^{20}$ The changes of the IR spectrum of the adsorbed chromate and citrate species on the $\alpha-\mathrm{Fe}_{2} \mathrm{O}_{3}$ film can be considered to determine the number of structurally different surface complexes when considering their binding mode based on the absence or emergence of absorption bands and shifts in their frequency.
Johnston et $a .^{5}$ indicated chromate mainly formed inner sphere complexes with $\alpha-\mathrm{Fe}_{2} \mathrm{O}_{3}$. From a quantitative point of view, the absorbance signal of the adsorbed chromate increased as the solution $\mathrm{pH}$ decreased in previous large batch studies. ${ }^{21-25}$ Additionally, the spectra of adsorbed chromate on the $\alpha-\mathrm{Fe}_{2} \mathrm{O}_{3}$ film were significantly different from the spectrum of aqueous chromate, which produced a single peak at $880 \mathrm{~cm}^{-1} \cdot{ }^{26}$ Chromate is adsorbed to the $\alpha-\mathrm{Fe}_{2} \mathrm{O}_{3}$ by electrostatic attraction and ligand exchange, resulting in the formation of monodentate complexes, with simultaneous desorption of surface hydroxyl groups from the iron surface sites. The complex geometry of the surface includes bidentate and monodentate complexes at low $\mathrm{pH}$. Monodentate complexation is also a precursor for the formation of bidentate complexes. ${ }^{27}$

Citric acid can also adsorb onto $\alpha-\mathrm{Fe}_{2} \mathrm{O}_{3}$ through electrostatic attraction and surface ligand exchange mechanisms. ${ }^{28}$ Citric acid formed innersphere complexes with the surface of $\alpha-\mathrm{Fe}_{2} \mathrm{O}_{3}$ (ref. 29) and symmetrical monodentate and bidentate surface complexes. ${ }^{30}$ Protons generally dissociate from citric acid at three different $\mathrm{pH}$ values $\left(\mathrm{p} K_{\mathrm{a} 1}=3.13, \mathrm{p} K_{\mathrm{a} 2}=4.76\right.$, and $\left.\mathrm{p} K_{\mathrm{a} 3}=6.40\right) .{ }^{29}$ As shown in Fig. 3 , the first two prominent IR bands were assigned to the asymmetric $\left(\nu_{\mathrm{as}}\right)$ and symmetric $\left(\nu_{\mathrm{s}}\right)$ stretching vibrations of the carboxylate $\left(-\mathrm{COO}^{-}\right)$groups, which were located at $1570-1595 \mathrm{~cm}^{-1}$ and $1400 \mathrm{~cm}^{-1},{ }^{29}$ respectively. The bands at $1270 \mathrm{~cm}^{-1}$ and $1740 \mathrm{~cm}^{-1}$ were interpreted as the bands of vibrational stretching and bending of $\mathrm{C}=\mathrm{O}$ and $\mathrm{C}-\mathrm{O}$ in the $-\mathrm{COOH}$ groups of citric acid, respectively, because at least one carboxylic group likely remained in the protonated state under the experimental conditions $\left(\mathrm{pH}<\mathrm{p} K_{\mathrm{a} 3}\right){ }^{29}$ When the solution $\mathrm{pH}$ was greater than the $\mathrm{p} K_{\mathrm{a} 3}$, these two bands gradually disappeared, as shown in Fig. 3. Therefore, citric acid could form monodentate or bidentate ring complexes with the $\alpha$ $\mathrm{Fe}_{2} \mathrm{O}_{3}$ surface. $^{30}$

3.3.2 Roles of $\alpha-\mathrm{Fe}_{2} \mathrm{O}_{3}$ in electron and energy transport. Several studies have suggested that small band gap semiconductors, such as ferrihydrite, goethite, $\mathrm{TiO}_{2}$ and bayerite, can act as conduits for electron transfer between electron donors and acceptors. ${ }^{\mathbf{8}, 31-33}$ The surface of $\alpha-\mathrm{Fe}_{2} \mathrm{O}_{3}$ could also provide a pathway for energy and electron transport from the adsorbed citric acid to chromate. Batch experiments have confirmed that $\mathrm{Cr}(\mathrm{VI})$ could be reduced to $\mathrm{Cr}(\mathrm{III})$ by citric acid in the presence of $\alpha-\mathrm{Fe}_{2} \mathrm{O}_{3}$. According to the studies of Lan et al. ${ }^{6,34}$ and Sarkar et al., ${ }^{7}$ however, citric acid could hardly reduce $\mathrm{Cr}(\mathrm{vI})$ in solution in the absence of minerals or metal ions.

The binding energies of different complexing structures of $\mathrm{HCrO}_{4}{ }^{-}$and citric acid adsorbed on $\alpha-\mathrm{Fe}_{2} \mathrm{O}_{3}$ at $\mathrm{pH} 4.0$ were calculated by using DFT, as shown in Table 1 . Both citrate and $\mathrm{HCrO}_{4}{ }^{-}$ions have similar adsorption energies of approximately $-70 \mathrm{~kJ} \mathrm{~mol}^{-1}$. Co-adsorption could spontaneously occur because the free energy dropped significantly $\left(-106.25 \mathrm{~kJ} \mathrm{~mol}^{-1}\right)$; however, the binding energy of the co-adsorption state remained relatively unchanged, which indicated that co-adsorption only occurred as a transitional state and was unstable. Based on calculations of the HOMO, the most active electron in citrate is concentrated in the $-\mathrm{COO}^{-}$radicals. The active electron density shifted to the $\mathrm{Fe}-\mathrm{O}$ bond after citrate was adsorbed to an iron cluster. After co-adsorption with $\mathrm{Cr}(\mathrm{vI})$, the most active electrons 
were shared by $\mathrm{HCrO}_{4}{ }^{-}$and the iron cluster, indicating that electrons were transferred from the carboxyl groups of citrate to $\mathrm{Cr}(\mathrm{vI})$ via the $\mathrm{Fe}-\mathrm{O}$ bond of $\alpha-\mathrm{Fe}_{2} \mathrm{O}_{3}$.

\section{Conclusions}

This study provides molecular level insights regarding coadsorption and the interactions of $\mathrm{Cr}(\mathrm{vI})$ and citrate on the $\alpha$ $\mathrm{Fe}_{2} \mathrm{O}_{3}$ surface. The in situ ATR-FTIR spectroscopy results show that $\mathrm{Cr}(\mathrm{vI})$ and citrate adsorbed to the $\alpha-\mathrm{Fe}_{2} \mathrm{O}_{3}$ surface and formed inner-sphere complexes. Furthermore, the DFT calculations indicated that the adsorption of both $\mathrm{Cr}(\mathrm{vI})$ and citrate on the surface of $\alpha-\mathrm{Fe}_{2} \mathrm{O}_{3}$ was energetically favourable. The coadsorption of ions on the surface of $\alpha-\mathrm{Fe}_{2} \mathrm{O}_{3}$ could lead to electron transfer from the carboxyl group of citrate to $\operatorname{Cr}(\mathrm{vI})$, which would drive the reduction of $\mathrm{Cr}(\mathrm{VI})$ to $\mathrm{Cr}$ (III). Collectively, the in situ ATR-FTIR spectroscopy and adsorption energy results and the IR spectrum predicted by DFT theory show that the interactions between $\mathrm{Cr}(\mathrm{vI})$ and citrate at the $\alpha-\mathrm{Fe}_{2} \mathrm{O}_{3}$-water interface can be theoretically and experimentally explained. Given the ubiquitous co-existence of $\alpha-\mathrm{Fe}_{2} \mathrm{O}_{3}$ and low molecular weight organic acids in natural environments, this study could be used to understand the fundamental mechanisms that determine the fate of $\mathrm{Cr}(\mathrm{vI})$ in the environment.

\section{Conflicts of interest}

There are no conflicts of interest to declare.

\section{Acknowledgements}

This work was financially supported by the National Science Foundation of China (Grants No. 51309214 \& No. 21507138), the Natural Science Foundation of Jiangsu Province, China (Grants No. SBK2015041561), the National High Technology Research and Development Program (2013AA06A208), and the Science and Technology Service Network Initiative (STS, KFJ-EW-STS091). We thank Prof. Cheng Gu at Nanjing University for performing the in situ ATR-FTIR analysis.

\section{References}

1 C. P. Johnston and M. Chrysochoou, Environ. Sci. Technol., 2016, 50, 3589-3596.

2 Z.-N. Huang, X.-L. Wang and D.-S. Yang, Water Sci. Eng., 2015, 8, 226-232.

3 J. Hu, G. Chen and I. M. Lo, Water Res., 2005, 39, 4528-4536.

4 K. Matern and T. Mansfeldt, Environ. Chem., 2016, 13, 674681.

5 C. P. Johnston and M. Chrysochoou, Geochim. Cosmochim. Acta, 2014, 138, 146-157.

6 C. Li, Y.-Q. Lan and B.-L. Deng, Pedosphere, 2007, 17, 318323.

7 B. Sarkar, R. Naidu, G. S. R. Krishnamurti and M. Megharaj, Environ. Sci. Technol., 2013, 47, 13629-13636.

8 B. Deng and A. T. Stone, Environ. Sci. Technol., 1996, 30, 2484-2494.
9 J. W. Yang, Z. S. Tang, R. F. Guo and S. Q. Chen, Environ. Prog. Sustainable Energy, 2008, 27, 302-307.

10 G. Yang, L. Tang, Y. Cai, G. Zeng, P. Guo, G. Chen, Y. Zhou, J. Tang, J. Chen and W. Xiong, RSC Adv., 2014, 4, 5836258371.

11 R. Dai, C. Yu, J. Liu, Y. Lan and B. Deng, Environ. Sci. Technol., 2010, 44, 6959-6964.

12 J. D. Kubicki, K. D. Kwon, K. W. Paul and D. L. Sparks, Eur. J. Soil Sci., 2007, 58, 932-944.

13 C. P. Johnston and M. Chrysochoou, Environ. Sci. Technol., 2012, 46, 5851-5858.

14 E. Cancès, B. Mennucci and J. Tomasi, J. Chem. Phys., 1997, 107, 3032.

15 K. Nakamoto, Infrared and Raman Spectra of Inorganic and Coordination Compounds, Theory and Applications in Inorganic Chemistry, Wiley, Hoboken, NJ, 2008.

16 V. T. Bodunde, F. A. Adekola and N. Abdus-Salam, J. N. C. Acad. Sci., 2013, 129, 24-33.

17 S. Yin and D. E. Ellis, Surf. Sci., 2009, 603, 736-746.

18 N. Bhandari, D. B. Hausner, J. D. Kubicki and D. R. Strongin, Langmuir, 2010, 26, 16246-16253.

19 J.-J. Max and C. Chapados, J. Phys. Chem. A, 2004, 108, 33243337.

20 K. Axe and P. Persson, Geochim. Cosmochim. Acta, 2001, 65, 4481-4492.

21 D. Rai, L. Eary and J. Zachara, Sci. Total Environ., 1989, 86, 15-23.

22 O. Ajouyed, C. Hurel, M. Ammari, L. B. Allal and N. Marmier, J. Hazard. Mater., 2010, 174, 616-622.

23 D. D. Maksin, A. B. Nastasović, A. D. Milutinović-Nikolić, L. T. Suručić, Z. P. Sandić, R. V. Hercigonja and A. E. Onjia, J. Hazard. Mater., 2012, 209, 99-110.

24 T. J. Reich and C. M. Koretsky, Geochim. Cosmochim. Acta, 2011, 75, 7006-7017.

25 G. Du, Z. Li, L. Liao, R. Hanson, S. Leick, N. Hoeppner and W.-T. Jiang, J. Hazard. Mater., 2012, 221, 118-123.

26 M. M. Hoffmann, J. G. Darab and J. L. Fulton, J. Phys. Chem. A, 2001, 105, 1772-1782.

27 P. R. Grossl, M. Eick, D. L. Sparks, S. Goldberg and C. C. Ainsworth, Environ. Sci. Technol., 1997, 31, 321-326.

28 W. Stumm and E. Wieland, in Aquatic Chemical Kinetics: Reaction Rates of Processes in Natural Waters. Environmental Science and Technology Series, ed. W. Stumm, John Wiley \& Sons, New York, 1990, pp. 367-400.

29 I. A. Mudunkotuwa and V. H. Grassian, J. Am. Chem. Soc., 2010, 132, 14986-14994.

30 O. W. Duckworth and S. T. Martin, Geochim. Cosmochim. Acta, 2001, 65, 4289-4301.

31 D. E. Latta, J. E. Bachman and M. M. Scherer, Environ. Sci. Technol., 2012, 46, 10614-10623.

32 B. Deng and A. T. Stone, Environ. Sci. Technol., 1996, 30, 463472.

33 B. Flockhart, S. Uppal and R. Pink, Trans. Faraday Soc., 1971, 67, 513-525.

34 Y. Lan, C. Li, J. Mao and J. Sun, Chemosphere, 2008, 71, 781787. 